\title{
Health panorama of the Afro-Brazilian population: a systematic review
}

\author{
Jucier Gonçalves Júnior 1*, Jair Paulino de Sales 2, Carlos Augusto Carvalho de Vasconcelos 3, \\ Modesto Leite Rolim Neto 4, Estelita Lima Cândido 4,5
}

${ }^{1}$ Department of Internal Medicine, Division of Rheumatology, Universidade de São Paulo (USP), São Paulo, Brazil.

${ }^{2}$ Post Graduate Program in Ciências da Computação, Universidade Federal de Pernambuco (UFPE), Recife, Brazil.

${ }^{3}$ Departament of Nutrition, Universidade Federal do Pernambuco (UFPE), Recife, Brazil.

${ }^{4}$ Post Graduate Program in Health Sciences, Faculty of Medicine, Universidade Federal do Cariri (UFCA), Barbalha, Brazil.

${ }_{5}$ Post Graduate Program in Desenvolvimento Regional Sustentável, Universidade Federal do Cariri (UFCA), Juazeiro do Norte, Brazil.

Correspondence: Jucier Gonçalves Júnior, Doutor Arnaldo Avenue, nº 455, Zip Code: 01246-903, São Paulo State, SP, Brazil. Phone: +55 11-3061-7176. Email: juciergjunior@hotmail.com.

Received on: Jul 26, 2021. Accepted on: Aug 3, 2021. Available online: Aug 4, 2021.

\begin{abstract}
In the present study, we sought to identify the current health panorama of the Afro-Brazilian population in the period from 2007 to 2021, based on a systematic review study. The nineteen selected studies allowed the creation of two thematic groups: Epidemiological aspects of pathologies in the afro-brazilian people and Health epidemiological aspects of the afro-brazilian women. We identified that some common chronic pathologies are Metabolic Syndrome (Hypertension, DM 2, Obesity) and Chronic Renal Insufficiency; infectocontagious pathologies like HIV/AIDS, tooth decay and Chagas disease; and mental disorders. In addition, smoking during pregnancy and anemia seem to be more prevalent in black women.

Keywords: Ethnicity and Health; Health of Ethnic Minorities; Public health; Equity; Health of the Afro-brazilian population.
\end{abstract}

\section{Introduction}

Afro-brazilian population claims to health system access increased in the second half of the 20th century. They had a strong participation of popular movements and supported the process that originated the Sanitary Reform and the Brazilian Unified Health System (SUS) [1] in the future. However, even though this developing system promoted universality, equity and integrality concepts, an environment of inequalities, differences and iniquities was its real configurations [2].

The Annual Report of Racial Inequalities in Brazil (2009-2010) showed a scenario of inequalities that varied from reproductive health to 
dental treatment. It emphasized the disregard for the well-being of social groups that are victims of racism, which is designed as a socio and historical determined context $[3,4]$. Thus, in Brazil of the 21st century, white, Afro-Brazilian (black and pardo) and Indigenous populations still occupy different social spaces, which reflects directly in the most common social indicators like schooling, work and health conditions $[5,6]$. Thus, race as well as gender and sexual orientation are social markers of difference, i.e. an explanatory variable for inequalities [6].

Based on the government point of view, the Brazilian Department of Health published the Política Nacional de Saúde Integral da População Negra (PNSIPN - Integral Health National Policy of the Black Population) in 2009, approved by the National Health Board in 2006 and that has been discussed since the creation of the Afro-brazilian population Technical Committee of Health in 2004 [7]. São Paulo State was the precursor in this process, because it was the first to incorporate the "race/color" subject in 1990 in health information systems, even though it was done only because of the popular pressure [8]. Nevertheless, the population and health professionals seem to be unaware of how racism impacts on life, access to services and quality of care [9]. It shows the need of a continuous elaboration of studies in order to acquire updated data that reinforce race equality fight.
This study was based on the following guiding question: what is the health epidemiological profile of the Afro-Brazilian population? This review highlights Afro-Brazilian people as important ethnic creators in Brazil, influencing several national sociocultural manifestations. However, historically, Afro-Brazilian people have not been included as a target population for state policies and only after the 1988 Brazilian Constitution did social discussions by these and other minority groups gain strength in the national debate.

Our hypothesis is that despite government efforts and discussion generated on society, Public Inclusion Policies have become incipient as they do not reach this population as a whole and have discrete counter measurements when they do so. But the extent to which social disparities show the health care character of the AfroBrazilian population is still not quite clear in literature.

\section{Methodology}

\section{Design and participants}

Systematic Review according to the PRISMA protocol (http://www.prisma-statement.org/), whose studies were largely chosen using the Biblioteca Virtual em Saúde (BVS), which hosts known databases and those of PubMed. 


\section{Procedure}

The following keywords were used: \#1"incidence" [MeSH]; \#2"prevalence;" [MeSH]; and \#3 "health equality" [MeSH]; \#3"health inequality" [MeSH]; \#4"african continental ancestry group" [MeSH]; and \#5 "Brazil" [MeSH]. Their equivalent terms in Portuguese were also used.

The period researched in literature was from July $1^{\text {st }}$ of 2007 to July $26^{\text {th }}$ of 2021 . The 2007-2021 period was chosen for the search in order to show the epidemiological data closer to the current reality and their evolution in the last ten years.

Data were collected in July of 2021. Manuscripts were mainly chosen through the analysis of titles and abstracts.

\section{Data analysis}

The articles were analyzed according to the following eligibility criteria (Figure 1): (1) articles including at least one combination of the terms described in the search strategy in their titles; (2) articles written in English, Portuguese or Spanish; (3) articles that discussed about socioeconomic indicators of the Afro-descendant population that live in Brazil; (4) original studies with full text accessible through the Journal Portal of the Coordination for the Improvement of Higher Education Personnel (CAPES), which is a virtual library created by the Brazilian Department of Health with restricted content to authorized users. We excluded: (1) non-original studies, such as letters to the editor, prefaces, short communications, corrections /errata, comments, editorials, reviews, papers, dissertations, and theses. Manuscripts found in more than one of the databases were accounted only once. To ensure more outcome reliability, data were collected by two researchers individually and divergences were solved by a third senior researcher.

Then, each article of the sample was fully read, and data were added to a spreadsheet that included author and year, title, study sample, study type, main outcomes, and conclusions (Table 1).

Some articles were excluded because they did not provide enough data for a comparison between several ethnic groups, due to the fact they did not divide data into different races, nor they focused on a certain group to the detriment of the others. Articles that considered quilombolas (maroons, in English) as a unique ethnic group are an example, because such fact does not follow the current mixed-race reality of these communities.

\section{Ethics approval}

This study followed all the ethical requirements of Helsinki Declaration and Resolution 510/2016 of the Brazilian Health National Council. It is a Literature Review study; therefore, it does not need to be submitted to the Ethics Committee in Research with Human Beings. 


\section{Results (Review)}

According to the adopted strategy, 65 manuscripts were firstly chosen. After complete analysis of the titles, abstracts and manuscripts, we obtained 19 articles according to the eligibility criteria and, therefore, we excluded 46 (Figure 1). The sample was divided into two predetermined categories, as follows: Epidemiological aspects of pathologies in the afro- brazilian people; and Health epidemiological aspects of the AfroBrazilian women.

Of the 19 chosen studies, nine [10-18] belong to the subtheme regarding general epidemiological aspects of Afro-Brazilian and ten [19-28] were more focused on Afro-Brazilian women's health.

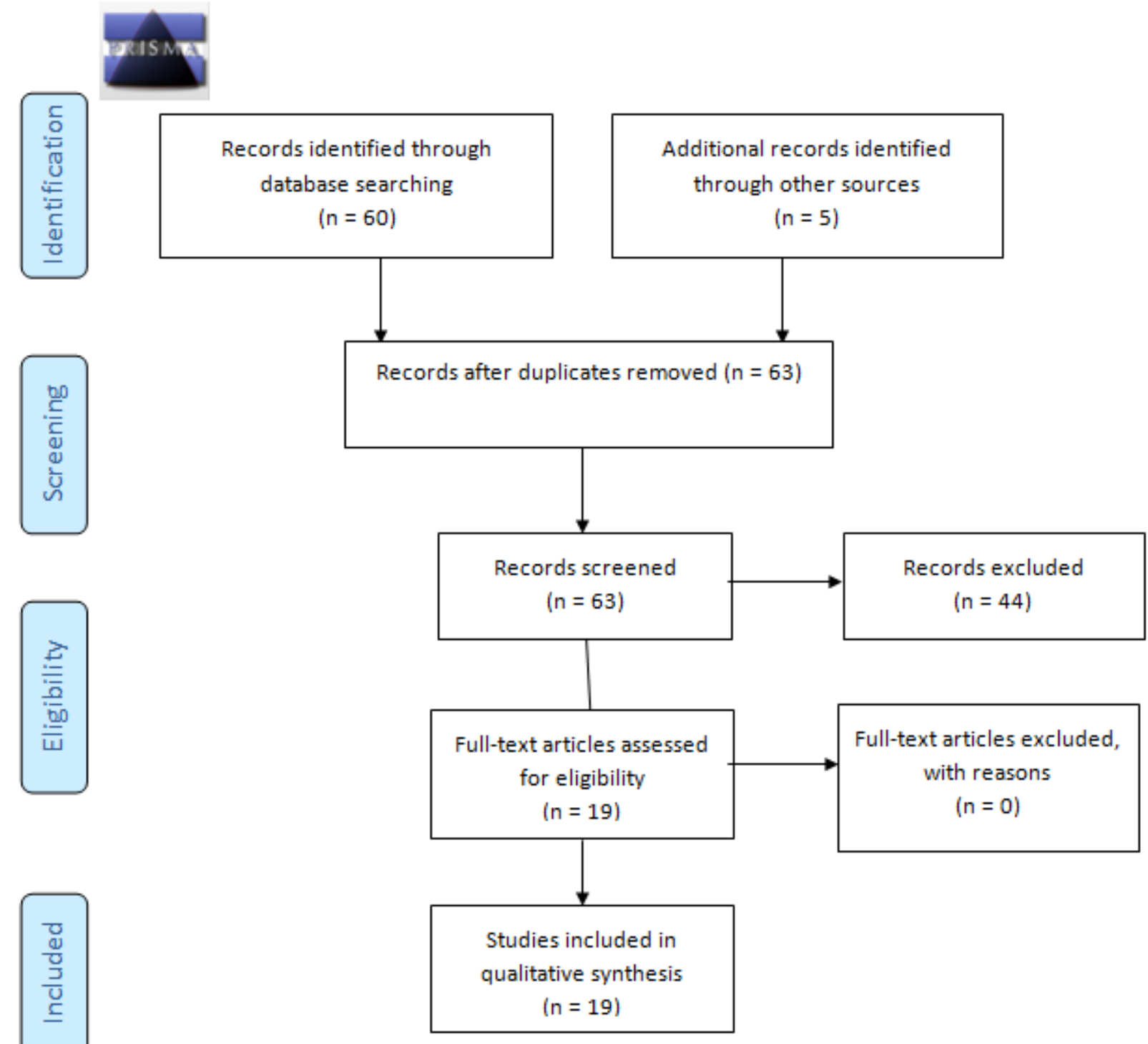

Figure 1. PRISMA flow diagram. 
Table 1. Main findings.

Epidemiological aspects of pathologies in the afro-Brazilian population

\begin{tabular}{|c|c|c|c|}
\hline Authors & Journal & Sample & $\begin{array}{c}\text { Main Findings in the } \\
\text { Afro-Brazilian } \\
\text { population }\end{array}$ \\
\hline Barreto et al., 2016 [10] & $\begin{array}{c}\text { J Epidemiol } \\
\text { Community Health }\end{array}$ & $\begin{array}{l}\text { 14,636 public service } \\
\text { employees of }(35-74 \\
\text { years old) in Belo } \\
\text { Horizonte, Porto } \\
\text { Alegre, Rio de Janeiro, } \\
\text { Sao Paulo and Vitória }\end{array}$ & $\begin{array}{l}\text { Afro-descendants had } \\
\text { higher rates of chronic } \\
\text { kidney disease (OR=1.23; } \\
95 \% \text { CI } 1.03 \text { to } 1.47) \text {, and } \\
\text { pardos (OR=1.16; } 95 \% \text { CI } \\
1.00 \text { to } 1.35) \text {. }\end{array}$ \\
\hline $\begin{array}{l}\text { Lima-Costa et al., 2016a } \\
\text { [11] }\end{array}$ & Hypertension & $\begin{array}{l}1.271 \quad \text { participants } \\
\text { Bambuí/MG, Brazil } \\
\text { (with age } \geq 60 \text { ) }\end{array}$ & $\begin{array}{l}\text { Lower per capita income } \\
\text { and schooling } \\
\text { respectively correlated } \\
\text { with higher HAS indices } \\
\text { and worst blood pressure } \\
\text { control in Afro- } \\
\text { descendants. }\end{array}$ \\
\hline $\begin{array}{c}\text { Lima-Costa et al., } 2016 b \\
\text { [12] }\end{array}$ & $\begin{array}{l}\text { PLOS Neglected } \\
\text { Tropical Diseases }\end{array}$ & $\begin{array}{l}\text { 1,341 elderly ( } \geq 60 \text { years } \\
\text { old) residents in } \\
\text { Bambuí/MG, Brazil. }\end{array}$ & $\begin{array}{l}\text { Afro-descendants had } \\
\text { more infections by } \\
\text { Trypanosome cruzi. }\end{array}$ \\
\hline $\begin{array}{l}\text { Drummond et al., } 2015 \\
\text { [13] }\end{array}$ & PLoS One & $\begin{array}{l}5,367 \text { Brazilian } \\
\text { teenagers aged } 15 \text { to } 19 \\
\text { of the five macro } \\
\text { regions of Brazil. }\end{array}$ & $\begin{array}{l}\text { Tooth decay was seen in } \\
32 \% \quad 69 \% \\
\text { descendants and } \\
\text { individuals of mixed-race }\end{array}$ \\
\hline $\begin{array}{l}\text { Mariante-Neto et al., } \\
2015 \text { [9] }\end{array}$ & Transplante & $\begin{array}{l}206 \text { Afro-brazilian } \\
\text { women (23)/ white } \\
(183) \text { in the liver } \\
\text { transplant queue in } \\
\text { Porto Alegre, RS, } \\
\text { Brazil. }\end{array}$ & $\begin{array}{l}\text { The main etiology of liver } \\
\text { cirrhosis was the C Virus, } \\
\text { followed by alcohol and B } \\
\text { virus. }\end{array}$ \\
\hline $\begin{array}{c}\text { Kochergin, Proietti and } \\
\text { César } \\
2014[14]\end{array}$ & Public Health Journal & $\begin{array}{l}797 \text { adults of } \\
\text { quilombolas } \\
\text { communities in Vitória } \\
\text { da Conquista, BA, } \\
\text { Brazil. }\end{array}$ & $\begin{array}{l}74.2 \% \text { of the samples were } \\
\text { sedentary, } 30.4 \% \text { were } \\
\text { overweight and } 10.7 \% \\
\text { were obese, } 13.5 \% \text { had } \\
\text { depression and } 60.2 \% \text { had } \\
\text { some chronic disease. }\end{array}$ \\
\hline $\begin{array}{l}\text { Celeste et al., } \\
2013 \text { [15] }\end{array}$ & $\begin{array}{c}\text { Comunidade Dent Oral } \\
\text { Epidemiol. }\end{array}$ & 3,252 public employees. & $\begin{array}{l}22 \% \text { of Afro- } \\
\text { descendants presented } \\
\text { absence of all teeth. }\end{array}$ \\
\hline $\begin{array}{c}\text { Miranda et al., } 2013 \\
\text { [16] }\end{array}$ & Diabetes Care Prim & $\begin{array}{l}241 \quad(25.5 \%) \quad \text { Afro- } \\
\text { brazilian s, versus } 422 \\
(44.7 \%) \text { Mulatos and } 272 \\
(28.8 \%) \\
\text { Whites in Niterói, RJ, } \\
\text { Brazil. }\end{array}$ & $\begin{array}{l}\text { Afro- } \\
\text { descendants presented } \\
\text { higher index of HAS and } \\
\text { DM2 with higher levels of } \\
\text { HbA1c. }\end{array}$ \\
\hline Gigante et al., 2013 [17] & Public Health Nutrition & $\begin{array}{l}4297 \text { women in Pelotas, } \\
\text { RS, Brazil. }\end{array}$ & $\begin{array}{l}\text { Afro-descendants have } \\
\text { higher index of BMI 1- } \\
\mathrm{kg} / \mathrm{m}^{2} \text { in comparison with } \\
\text { whites. }\end{array}$ \\
\hline
\end{tabular}


Fiorio et al,. 2011 [18]
Rev Bras Epidemiol.

Population of Vitória, ES, Brazil, 32\% parda and $7 \%$ Afro-brazilian .
Afro-

descendants presented

higher rates of mental disorders/behaviors and deaths by external causes, the average of age of death was 33, which is lower than the white population's rate.

\section{Health epidemiological aspects of the afro-brazilian women}

\section{Authors}

Silveira et al., 2016 [19]

Mariante-Neto et al., 2015 [9]

Tabb et al., 2015 [20]

Bernardes et al., 2014

[21]

Carvalho et al., 2014

[22]

Boclin et al., 2014 [23]

Gabrielli et al., 2012

[24] Journal Sample

BMJ Open

Transplante

Ethn Saúde

BMC Pregnancy Childbirth

BMC Womens Health

8,687 samples of breast neoplasms of all Brazil in a lab in Botucatu, SP, Brazil.

1,475 female public employees in Rio de Janeiro, RJ, Brazil.

859 women, of which $88.5 \%$ were AfroPelotas, RS, Brazil who gave birth in 1982 $(5,909), 1993 \quad(5,223)$, $2004(4,201)$ and 2011$2012(6,275)$.

206 Afro-brazilian women (23)/ white (183) in the liver transplant queue in Porto Alegre, RS, Brazil.

810 pregnant women surveyed during 20-30 weeks of pregnancy in São Paulo, SP, Brazil.
Main Findings in the Afro-brazilian population

21,608 of women in The reduction in smoking during pregnancy was higher among white and high-income women.

The corrected MELD was higher for Afro-Brazilian women $(63.1 \%) \quad$ in comparison to white (26.1\%).

Afro-descendant pregnant women were more inclined to smoke during the pregnancy.

Afro-descendant AfroBrazilian women $(\mathrm{PR}=$ 1.19; $95 \%$ CI 1.04-1.36) and mulato $(\mathrm{PR}=1.14$; 95\% CI 1.02-1.26) presented inadequate use of basic and prenatal care. The Northern region, whose Afro-Brazilian culture influence is higher, presented 941 cases (3rd largest region of the country), the most common subtypes were LumA (24.1\%), LumB (37.1\%), HER2 (10.1\%)

Afro-descendants had higher incidence of Leiomyoma.

$8.5 \%$ of patients presented polycystic ovary 


\begin{tabular}{|c|c|c|c|}
\hline & & $\begin{array}{l}\text { brazilian, in Salvador, } \\
\text { Brazil. }\end{array}$ & syndrome. \\
\hline Gomes et al., 2013 [25] & $\begin{array}{c}\text { Caderno de Saúde } \\
\text { Pública }\end{array}$ & $\begin{array}{l}797 \text { quilombolas in } \\
\text { Vitória da Conquista, } \\
\text { BA, Brazil. }\end{array}$ & $\begin{array}{l}\text { Female quilombolas used } \\
\text { health service more. The } \\
\text { sample evaluated their } \\
\text { health as regular, bad or } \\
\text { very bad. }\end{array}$ \\
\hline Freitas et al., 2009 [26] & $\begin{array}{c}\text { International Journal of } \\
\text { Gynecology \& } \\
\text { Obstetrics }\end{array}$ & $\begin{array}{lr}2,171,032 & \text { primiparous } \\
\text { women } & \text { assisted } \\
\text { between } & 2003-2004 \text { in }\end{array}$ & $\begin{array}{l}\text { Afro-descendant women } \\
\text { were minority in hospital } \\
\text { births. In the States with }\end{array}$ \\
\hline & & $\begin{array}{l}\text { the Brazilian health } \\
\text { system, of whom } \\
451,741 \text { of them were } \\
\text { Afro-brazilian. } \\
1068 \text { HIV nositive }\end{array}$ & $\begin{array}{l}\text { low hospital coverage, } \\
64.9 \% \text { of women with } \\
\text { caesarean section were } \\
\text { Afro-Brazilian. } \\
\text { Afro-descendants had }\end{array}$ \\
\hline Lopes et al., 2007 [27] & $\begin{array}{l}\text { Revista de Saúde } \\
\text { Pública }\end{array}$ & $\begin{array}{l}1,068 \text { HIV positive } \\
\text { women older than } 18 \text { in } \\
\text { São Paulo, SP, Brazil. }\end{array}$ & $\begin{array}{l}\text { Afro-descendants had a } \\
\text { statically significant } \\
\text { relationship compared to } \\
\text { white in the variables - } \\
\text { schooling; monthly, } \\
\text { individual and family } \\
\text { income per capita; and } \\
\text { number of direct } \\
\text { dependents. }\end{array}$ \\
\hline $\begin{array}{l}\text { Fabian et al., } \\
2007 \text { [28] }\end{array}$ & $\begin{array}{l}\text { Cadernos de Saúde } \\
\text { Pública }\end{array}$ & $\begin{array}{l}312 \text { women aged } \\
\text { between } 20 \text { to } 60 \text { in São } \\
\text { Leopoldo, RS, Brazil. }\end{array}$ & $\begin{array}{l}\text { The highest prevalence of } \\
\text { anemia was in Afro- } \\
\text { Brazilian women ( } 54 \%) \\
\text { 3x higher compared with } \\
\text { white. }\end{array}$ \\
\hline
\end{tabular}

Legend: OR - Odds Ratio; PR - Prevalence Reason; CI - Confidence Interval; MG - Minas Gerais; ES Espírito Santo; RS - Rio Grande do Sul; RJ - Rio de Janeiro; SP -São Paulo; BA- Bahia; MA - Maranhão; HAS - Systemic Blood Hypertension; DM 2 - Diabetes Mellitus type 2; HbA1c - Glycated Hemoglobin.

\section{Discussion and Conclusion}

\section{Epidemiological aspects of pathologies in the afro-brazilian people}

Chronic kidney disease - CKD [10], diabetes (DM2) with higher levels of HbA1c [16], and lack of all teeth [15] or tooth decay for Afro-Brazilian people and [13] mulatos (they constitute the Brazilian ethnic groups that are the result of miscegenation between African and European) were more present in comparison with other ethnic-racial groups.

This can be explained by biological aspects, such as higher incidence of resistant hypertension and hard control on Afro-Brazilian people and their refractoriness to medications like angiotensin - converting - enzyme inhibitors (ACE inhibitors), and psychosocial factors, for instance, limited access to services. This population also shows more incidence of infectocontagious diseases like Chagas disease [11] when compared to 
the European-descendant population, and metabolic diseases like polycystic ovary Syndrome, in which 889 women, in a population studied at paper [24], were assessed and $88.9 \%$ were AfroBrazilian, with an $8.5 \%$ disease incidence [24]. However, since this study was conducted in the city of Salvador, Bahia State, in which there is a higher incidence of the Afro-Brazilian population, there is a bias here.

It is noteworthy that in these studies, lower per capita income, low schooling levels and, therefore, level of instruction for the development of health self-care had a higher impact on the prevalence of these diseases than specific biological characteristics of the Afro-Brazilian. A work conducted in Bambuí [12] highlighted that schooling levels ( $<4$ years) were statistically more correlated with high pressure levels (Adjusted $\quad \beta=2.92 ; \quad 95 \% \quad$ confidence interval, 0.85-4.99), whereas polygenic mutations that address African ancestry were not.

An interesting fact is that in a study about health self-assessment from a quilombola population of Vitória da Conquista, Espírito Santo, Brazil Southeast, skin color was pointed out as one of the justifications for those that assessed health condition as negative [14], a similar result also found in other studies [29,30]. Racism has been indicated as one of the reasons for ethnical-racial criteria eligibility as causers of inequalities in the health quality assessment. We also identified the prevalence of food insecurity in quilombos from a Brazilian Northeast rural area, which also have some associations with economic level and quantities of residents per house [19].

In the Afro-Brazilian population, unlike other ethnic-racial groups, there are higher mortality and lower life expectancy with a disparity of around 33 years in the median of deaths between Afro-Brazilian and white individuals according Fiorio et al [18]. Afro-Brazilian people show higher rates of deaths due to mental and behavioral disorders, as well as undefined causes [18]. A study published in 2014 [14] showed a depression incidence of $13.5 \%$ in Afro-descendants from the Bahia city Vitória da Conquista, and more than $60 \%$ of them had a chronic disease. These statistics are not universal. They even highlight there is no concrete correlation between race and mental health in literature; however, a positive incline has been seen towards this direction.

This group, probably due to their life conditions - more exposure to violence, poverty and insalubrious environments -, is more inclined to developing mental disorders. In addition, due to the lack of multidisciplinary team care in the outskirts of the cities, improper coverage of the Family Health Strategy and efficient public security presence in these places, which show a higher incidence of Afro-Brazilian people, afroBrazilian people would not have their causa mortis clarified.

\section{Health epidemiological aspects of afro- brazilian women}

After the study of HIV female carriers, statistically significant 
differences were found between AfroBrazilian and non-afro Brazilian women for variables like schooling; monthly, individual and family per capita income; number of direct dependents, correct knowledge of CD4 and viral load examinations, access to gynecologist and infectious disease specialist, and comprehension of what the infectious disease specialist explains during the medical appointment according Fabian et al [27]. Researches [17] in the city of São Paulo that compared Afro-Brazilian and non-Afro-Brazilian women found that Afro-Brazilian women are considered the group with the highest BMI, especially at the ages of 4 and 23, varying from 1 to $3 \mathrm{~kg} / \mathrm{m}^{2}$. Thus, they reinforce the multifactorial model that mainly involves social position variables to explain the higher percentage of sick people among Afro-Brazilian people.

In Miranda et al. afro-brazilian women waiting for liver transplant presented lower model for end-stage liver disease - MELD (26.1\%) than white women $(63.4 \%)$ [16], despite the same cirrhosis causes in both groups alcohol, C and B viruses, respectively. Also, afro-brazilian people are more inclined to kidney dysfunction; therefore, they show a lack of equity among women due to their ethnicity.

According the papers evaluated regarding gynecological and obstetric health issues, these patients presented a higher incidence of uterine fibroids [23] and more aggressive breast neoplasms, because when the values per region were divided, the Brazilian Northeast region, which has higher influence of the black in its constitution, provided higher rates of breast cancer with uncommon and severe mutations [22] and there was more smoking during pregnancy $[19,20]$.

In addition, a study carried out in Maranhão [21] shows that C-section delivery rates are lower in all the ethnic groups in comparison with white women, of whom Afro-Brazilian ones are a minority in hospital deliveries. This disparity becomes even more important in states with lower access to hospitals, and causal factors include more advanced maternal age, high schooling levels, and prenatal followup. Such situation shows that Afrobrazilian women have lower access to health services and undergo procedures that are available in the public health system, but they usually do not have the possibility of choosing how they want to give birth. Such fact is mainly associated with poor financial conditions of AfroBrazilian pregnant women, even though there are many orientations in literature regarding the best delivery type.

Therefore, the most of these diseases are strictly correlated with poor socioeconomic variables, such as low income, housing in insalubrious places, lack of access to basic sanitation, to quality food, to public security, to health services and to health prevention and promotion media. In parallel, we noticed that the interest for such subject is still new in the country and is shown by the disparity of indicators in different regions of Brazil.

This suggests the need of increasing discussion about racial inequalities in health by promoting public policies of accessibility to services 
in the four spheres - primary, secondary, tertiary and quaternary attention, as well as a bolder mapping of social indicators divided and compared by regions to subsidize future interventions.

\section{References}

[1] Werneck J. Racismo institucional e saúde da população negra. Saúde Soc. 2016;25(3):535-549.

[2] Paim JS, Silva LMV. Universalidade, integralidade, equidade e SUS. Boletim do Instituto de Saúde. 2010;12(2).

[3] Paixão M, Rosseto I, Carvano LM. (Org.). Relatório Anual das Desigualdades Raciais no Brasil 20092010. Garamond Universitária: Rio de Janeiro, 2011.

[4] Lages SRC, Tavares NO, Santos SV, Carvalho MAS, Maciel LFR. Pesquisas em Psicologia Social no Campo da Saúde da População Negra no Brasil. Rev. Psicol. 2014;13(1):1-10.

[5] Batista LE, Monteiro RB, Medeiros RA. Iniquidades raciais e saúde: o ciclo da política de saúde da população negra. Saúde em Debate, (2013);37(99):681-690.

[6] Batista MCA, Perez OC. Participação política e marcadores sociais da diferença: reflexões sobre o tema no campo da ciência política. Conexão Política, (2016); 5(1):23-34.

[6] Brasil. Ministério da saúde. Portaria GM/MS n 1.678 , de 13 de agosto de 2004. Cria Comitê Técnico para subsidiar o avanço da equidade na
Atenção à Saúde da População Negra, e dá outras providências. Diário Oficial da União 2004.

[7] São Paulo. Secretaria municipal da saúde. Portaria $n^{\circ}$ 696. Diário Oficial da Cidade de São Paulo 1990; 30 mar.

[8] Mariante-Neto G, Brandão ABM. Model for End-Stage Liver Disease: Is Sex-Based Creatinine Correction a Viable Strategy for Black Females? Transplantation, 2015;99(11): 2337-2340.

[9] Barreto SM, Ladeira RM, Duncan BB, Schmidt MI, Lopes AA, Benseñor IM, Chor D, Griep RH, Vidigal PG, Ribeiro AL, Lotufo PA, Mill JG. Chronic kidney disease among adult participants of the ELSA-Brasil cohort: association with race and socioeconomic position. J Epidemiol Community Health. 2016 Apr;70(4):380-9. doi: 10.1136/jech-2015205834.

[10] Lima-Costa MF, Macinko J, Mambrini JV, Peixoto SV, Pereira AC, Tarazona-Santos E, Ribeiro AL. Genomic African and Native American Ancestry and Chagas Disease: The Bambui (Brazil) Epigen Cohort Study of Aging. PLoS Negl Trop Dis. 2016 May 16;10(5):e0004724. doi: 10.1371 / journal.pntd.0004724.

[11] Lima-Costa MF, Mambrini JVM, Leite MLC, Viana PSW, Firmo JOA, Loyola Filho AI, Gouveia MH, Leal TP, Pereira AC, Macinko J, Santos EMT. Socioeconomic Position, But Not African Genomic Ancestry, Is Associated With Blood Pressure in the Bambui-Epigen (Brazil) Cohort Study of Aging Novelty 
and Significance. Hypertension, (2016); 67(2):349-355.

[12] Drummond AM, Ferreira EF, Gomes VE, Marcenes W. Inequality of Experience of Dental Caries between Different Ethnic Groups of Brazilians Aged 15 to 19 Years. PLoS One. 2015 Dec 22;10(12):e0145553. doi: 10.1371/journal.pone.0145553.

[13] Kochergin CN, César CC, Proietti FA. Comunidades quilombolas de Vitória da Conquista, Bahia, Brasil: autoavaliação de saúde e fatores associados. Cad Saude Publica, 2014; 1487-1501.

[14] Celeste RK, Gonçalves LG, Faerstein $\mathrm{E}$, Bastos JL. The role of potential mediators in racial inequalities in tooth loss: the Pró-Saúde study. Community Dent Oral Epidemiol. 2013 Dec;41(6):509-16. doi: 10.1111/cdoe.12051.

[15] Miranda VA, Cruz Filho RA, Oliveira TS, Moscavitch SD, Kang HC, Chagas SVM et al. Racial differences in HbA1c: A cross-sectional analysis of a Brazilian public primary care population. Prim Care Diabetes, 2013; 7(2):135-141.

[16] Gigante DP, Victoria CG, Matjasevich A, Horta BL, Barros FC. Association of family income with BMI from childhood to adult life: a birth cohort study. Public Health Nutr, 2013;16(2):233-9.

[17] Fiorio NM, Flor LS, Padilha M, Castro DS. Mortalidade por raça/cor: evidências de desigualdades sociais em Vitória (ES), Brasil. Rev. bras. epidemiol, 2011;14(3):522-530.

[18] Silveira MF, Matijasevich A, Menezes AMB, Horta BL, Santos IS, Barros AJD, Barros FC, Victoria CG. Secular trends in smoking during pregnancy according to income and ethnic group: four population-based perinatal surveys in a Brazilian city. BMJ Open, 2016; 6(2):e01012.

[19] Tabb KM, Huang H, Menezes PR, Azevedo e Silva G, Chan YF, FaisalCury A. Ethnic differences in tobacco use during pregnancy: findings from a primary care sample in São Paulo, Brazil. Ethn Health. 2015;20(2):209-17. doi: 10.1080/13557858.2014.907390.

[20] Bernardes ACF, Silva RA, Coimbra LC, Alves MTSSB, Queiroz RCS, Batista RFL, Bettiol H, Barbieri MA, Silva AAM. Inadequate prenatal care utilization and associated factors in São Luís, Brazil. BMC Pregnancy and Childbirth. 2014; 14(266).

[21] Carvalho FM, Bacchi LM, Pincerato KM, Van de Rijn M, Bacchi CE. Geographic differences in the distribution of molecular subtypes of breast cancer in Brazil. BMC Women's Health, 2014; 14(1).

[22] Boclin KLI, Faerstein E, Szklo M. Does life-course socioeconomic position influence racial inequalities in the occurrence of uterine leiomyoma? Evidence from the Pro-Saude Study. Cad. Saúde Pública. 2014;30(2):305-317. 
[23] Gabrielli L, Aquino EMI. Polycystic ovary syndrome in Salvador, Brazil: a prevalence study in primary healthcare. Reproductive Biology and Endocrinology. 2012;10(96).

[24] Gomes KO, Reis EA, Guimarães MDC, Cherchiglia ML. Utilização de serviços de saúde por população quilombola do Sudoeste da Bahia, Brasil Cad. Saúde Pública. 2013; 29(9):18291842.

[25] Freitas PF, Drachler Mde L, Leite JC, Marshall T. Inequalities in cesarean delivery rates by ethnicity and hospital accessibility in Brazil. Int J Gynaecol Obstet. 2009 Dec;107(3):198-201. doi: 10.1016/j.ijgo.2009.08.017.

[26] Lopes F, Buchalla CM, Ayres JRCM. Mulheres negras e não-negras e vulnerabilidade ao HIV/Aids no estado de São Paulo, Brasil. Rev Saúde Pública. 2007;41(2):39-46.

[27] Fabian C, Olinto MTA, Dias-dacosta JS, Bairro SF, Nacul LC. Anemia prevalence and associated factors among adult women in Sao Leopoldo, Rio Grande do Sul, Brazil. Cad. Saúde Pública. 2007;23(5): 1199-1205.

[28] Barata RB, Almeida MF, Montero $\mathrm{CV}$, Silva ZP. Health inequalities based on ethnicity in individuals aged 15 to 64 , Brazil, 1998. Cad Saúde Pública. 2007; 23:305-13.

[29] Guerrero AFH, Silva DO, Toledo LM, Guerrero H, Teixeira P. Mortalidade infantil em remanescentes de quilombos do Município de
Santarém - Pará, Brasil. Saúde Soc. 2007;16:103-10.

Conflict of interest: The author declares no conflicts of interest.

Acknowledgements: The authors would like to thank the Núcleo de desenvolvimento e aplicação de estratégias para o combate a doenças e agravos das coletividades humanas of the Faculty of Medicine (FAMED) of the Federal University of Cariri (UFCA), Post Graduate Program in Health Sciences of the FAMED - UFCA, Post Graduate Program in Desenvolvimento Regional Sustentável - UFCA, Scientific Writing Lab of the FAMED - UFCA and Departament of Internal Medicine Divison of Rheumathology - São Paulo University (USP).

Funding: There was no financial support for the development of this research.

How to cite this article: Júnior JG, Sales JP, Vasconcelos CAC, Neto MLR, Cândido EL. Health panorama of the Afro-Brazilian population: a systematic review. Brazilian Journal of Case Reports. 2021 Jul-Sep; 01(3):74-85. 